\title{
PENGUATAN KAPASITAS KADER DALAM AKSELERASI PENINGKATAN CAKUPAN DAN MUTU IMUNISASI DI RANUPAKIS KECAMATAN KLAKAH
}

\author{
Nurul Hayati, Raden Endro Sulistyono, Sri Wahyuningsih, dan Primasari Mahardhika Rahmawati \\ Universitas Jember \\ E-mail: nurulhyt@unej.ac.id
}

\begin{abstract}
ABSTRAK. Program Indonesia Sehat merupakan salah satu program kesehatan dalam Meningkatkan Kualitas Hidup Manusia Indonesia. Terdapat 12 indikator indonesia sehat diantaranya adalah balita mendapat imunisasi lengkap. Imunisasi merupakan hal yang sangat penting dilakukan mengingat sudah semakin kuatnya bakteri atau virus yang dapat menyerang tubuh. Imunisasi ini umumnya dilakukan pada saat seseorang masih berumur balita. Pelaksanaan imunisasi dalam pelaksanaannya terkadang menemui beberapa kendala, diantaranya kelompok/keluarga/ individu yang kontra. Penyebabnya adalah tingkat pendidikan yang rendah, persepsi yang salah, pandangan agama, dan faktor lingkungan lainnya. Kelompok Riset (Keris) Nurse.co.id berusaha untuk menemukan langkah dalam pemecahan masalah kesehatan khususnya pelaksanaan imunisasi yaitu dengan FASTER (Fasilitasi dan pendampingan kader posyandu) dengan pendekatan budaya Pandalungan. FASTER ini diawali dengan komplain survey tentang pandangan budaya setempat terhadap pelaksanaan imunisasi. Complain survey ini merupakan salah satu strategi dalam pengkajian keperawatan komunitas yang menghasilkan janji perbaikan dan komitmen. Hasil komplain survey ini disinergikan dengan proses keperawatan selanjutnya yaitu intervensi, implementasi dan evaluasi keperawatan. Berbagai pendekatan dilakukan sesuai dengan hasil riset yang pernah dilakukan oleh anggota pengusul (Keris Nurse.co.id). Sesuai amanat keputusan menteri kesehatan nomor 279 tahun 2006 bahwa tujuan perkesmas adalah terwujudnya keluarga sehat mandiri tahap IV yaitu keluarga yang dapat melakukan promosi kesehatan. Sehingga harapan pengmas ini adalah terwujud masyarakat Ranupakis yang tahu, mau dan mampu memelihara kesehatan khususnya kesehatan balita (imunisasi) dan pada akhirnya tercapai tujuan program kesehatan.
\end{abstract}

Kata kunci: perberdayaan kader; cakupan, imunisasi

\section{STRENGTHENING THE CAPACITY OF CADRES IN THE ACCELERATION OF INCREASING THE COVERAGE AND QUALITY OF IMMUNIZATION IN RANUPAKIS, KLAKAH DISTRICT}

\begin{abstract}
The Healthy Indonesia Program is one of the health programs in Improving the Quality of Life of Indonesian Humans. There are 12 healthy Indonesian indicators including toddlers getting complete immunizations. Immunization is a very important thing to do given the growing strength of bacteria or viruses that can attack the body. This immunization is generally done when someone is still a toddler. Immunization in its implementation sometimes encounters several obstacles, including contra groups/families/individuals. The cause is low education levels, wrong perceptions, religious views, and other environmental factors. Nurse.co.id Research Group (Keris) is trying to find steps in solving health problems, especially the implementation of immunization, namely by FASTER (Posyandu cadre facilitation and assistance) with the Pandalungan cultural approach. This FASTER begins with a survey complaint about the views of local culture on the implementation of immunization. Complain survey is one of the strategies in community nursing review that results in promises of improvement and commitment. The results of this survey complaint are synergized with the next nursing process, namely intervention, implementation and evaluation of nursing. Various approaches are carried out by the results of research that has been carried out by members of the proposer (Keris Nurse.co.id). By the mandate of the Minister of Health Decree number 279 of 2006 that the purpose of the Community Health Insurance is the realization of a stage IV independent healthy family that is a family that can carry out health promotion. So that the hope of this community service is realized Ranupakis people who know, want and can maintain health, especially toddler health (immunization) and in the end, the health program objectives are achieved.
\end{abstract}

Key words: cadre empowerment; coverage, immunization

\section{PENDAHULUAN}

Program pengabdian kepada masyarakat adalah program yang berorientasi kepada permasalahan yang dihadapi oleh masyarakat berdasarkan pengamatan tiap disiplin ilmu terhdap perkembangan bidang kesehatan. Tujuan dilakukannya pengabdian kepada masyarakat adalah: menerapkan teori-teori keilmuan di bidang kesehatan untuk mengatasi masalah yang terjadi di lapangan sehingga dapat memberi manfaat pada masyarakat, berpartisipasi aktif dalam proses pembangunan kesehatan, meningkatkan pemberdayaan masyarakat dalam bidang kesehatan, meningkatkan kemampuan masyarakat akademik (dosen dan atau mahasiswa) dalam menerapkan teori-teori keilmuan baik secara mandiri maupun kelompok, membantu mengatasi permasalahan yang dihadapi pemerintah maupun masyarakat dengan metode ilmiah secara praktis, hal ini ditujukan untuk menciptakan perilaku masyarakat untuk hidup sehat (Kemenkes, 2014). ). Kesehatan merupakan hak azasi dan sekaligus sebagai investasi, sehingga perlu diupayakan, diperjuangkan dan ditingkatkan oleh setiap individu dan oleh seluruh komponen bangsa, agar masyarakat dapat menikmati hidup sehat, dan pada akhirnya dapat mewujudkan derajat kesehatan masyarakat yang optimal. Hal ini perlu dilakukan karena kesehatan bukanlah tanggung jawab pemerintah saja, namun merupakan tanggung jawab bersama antara pemerintah 
masyarakat, dan pihak swasta. Sumberdaya manusia yang sehat dan berkualitas merupakan modal utama atau investasi dalam pembangunan kesehatan. Posyandu (Pos Pelayanan Terpadu) merupakan salah satu bentuk Upaya Kesehatan Bersumberdaya Masyarakat (UKBM) yang dilaksanakan oleh, dari dan bersama masyarakat, untuk memberdayakan dan memberikan kemudahan kepada masyarakat guna memperoleh pelayanan kesehatan bagi ibu, bayi dan anak balita. Berdasarkan hasil Survei Demografi Kesehatan Indonesia (SDKI) tahun 2012, angka kematian bayi (AKB) 34/1000 kelahiran hidup dan angka kematian balita (AKBA) 44/1000 kelahiran hidup. Hasil survei Riskesdas tahun 2013 didapatkan data cakupan imunisasi HB-0 (79,1\%), BCG (87,6\%), DPTHB-3 (75,6\%), Polio-4 (77,0\%), dan imunisasi campak $(82,1 \%)$. Survei ini dilakukan pada anak usia $12-23$ bulan. Book1

Komisi fatwa majelis ulama indonesia (MUI) menimbang bahwa imunisasi, sebagai salah satu tindakan medis untuk mencegah terjadinya penyakit tertentu, bermanfaat untuk mencegah penyakit berat, kecacatan dan kematian. Berdasarkan beberapa uraian di atas terjadinya masalah terkait imunissi salah satunya juga terjadi di Kabupaten Lumajang yaitu di Wilayah Kecamatan Klakah. Kecamatan ini memiliki luas 83,64 Km2, terletak di belahan utara wilayah Kabupaten Lumajang, dengan ketinggian rata-rata $193 \mathrm{~m}$ dari permukaan laut, curah hujan $2119 \mathrm{~mm} /$ tahun. Sedangkan jarak dari ibukota Kabupaten Lumajang sejauh $17 \mathrm{Km}$, adapun jumlah penduduk 54.156 jiwa yang tersebar di 12 Desa serta terdiri dari 60 Dusun, 88 RW dan 8307 RT. Salah satu Desa yang terletak di Wilayah Kerja UPT Puskesmas Klakah adalah Desa Ranu Pakis. Luas wilayah kerja Ranupakis adalah 731 Ha,yang merupakan wilayah daratan. Desa Ranupakis memiliki batas-batas wilayah diantaranya yaitu : Sebelah Utara : Desa Tegal Randu, Sebelah Selatan : Desa Kebonan Sebelah Timur : Desa Duren, Sebelah Barat : Desa Klakah. Sejumlah 54,4 \% penduduk desa Ranupakis tergolong jenis etnis Madura (Pandalungan), dengan bahasa sehari-hari yaitu bahasa Madura. Program kesehatan di wilayah tersebut telah dijalankan oleh petugas ponkesdes/Puskesmas dan kader, salah satunya adalah posyandu Balita. Namun, dalam pelaksanaannya menghadapi beberapa kendala seperti minimnya keluarga yang mau melakukan imunisasi dengan alasan imunisasi menyebabkan balita semakin sakit panas (hipertensi), beberapa kali sudah diberi tahu dan diberikan sosialisasi tentang pentingnya imunisasi namun masih mendapat penolakan. Hasil FGD yang dilakukan sebelumnya juga didapatkan data bahwa terdapat permasalahan hampir di segala sisi agregat, mulai dari balita (menolak imunisasi, BBLR, gizi buruk.

\section{METODE}

Pelaksanaan pengmas diawali dengan melaksanakan complain survey berbasis budaya. Permasalahan kesehatan diinventarisir dengan beberapa tahapan FGD (Focus Group Discussion). FGD awal dilakukan pihak petugas kesehatan, tahap 2 dilakukan FGD dengan masyarakat, sedangkan sesi FGD ketiga dilakukan dengan masyarakat dan petugas kesehatan. Sesuai dengan konsep Perkesmas "Keperawatan Kesehatan Masyarakat" bahwa mitra harus dilibatkan mulai dari pengkajian hingga proses evaluasi. Proses pengkajian ini menggunakan teori "Sunrise Model” milik Leininger yang menjabarkan pentingnya perawat memahami 7 pokok pendekatan budaya meliputi Politik/kebijakan, Agama dan kepercayaan, Sosial masyarakat, Budaya yang dianut, Ekonomi, Tekhnologi dan Edukasi/pendidikan masyarakat. Saat Permasalahan sudah diinventarisir dan potensi budaya sudah terkaji maka dilakukan penentuan Strategi pelaksanaan percepatan Indonesia Sehat demi mewujudkan masyarakat Sehat mandiri. Intervensi berbasis budaya dengan memanfaatkan riset yang pernah dilakukan oleh kelompok riset Nurse.co.id. Strategi intervensi sesuai Leininger (transcultural) adalah negosisasi, maintenance dan juga restrukturisasi budaya. Beberapa SOP, Modul akan dihasilkan untuk diaplikasikan di desa binaan tersebut dengan melibatkan lintas sector terkait. Mahasiswa dilibatkan dalam pengabdian masyarakat ini mulai dari persiapan, pelaksanaan dan monitoring evaluasi.

\section{Prosedur Kerja Untuk Mendukung Realisasi Metode Yang Ditawarkan}

Kabupaten Lumajang Memiliki MPK (Masyarakat Peduli Kesehatan) dan ditingkat kecamatan akan dibentuk KMPK (Komunitas Masyarakat Peduli Kesehatan). Sebelumnya sudah terbentuk KMPK di 8 Puskesmas sehingga bisa bersinergi dengan KPMK yang akan dibentuk di Mojo, Kecamatan Padang. KMPK ini sebagai penyambung aspirasi masyarakat dengan petugas kesehatan sehingga akan menjadikan pelayanan kesehatan semakin prima dan terwujud keluarga sehat mandiri Tahap IV yaitu keluarga yang mempu melaksanakan peningkatan kesehatan dalam kehidupan sehari-hari.

\section{Keberlangsungan Program}

Diharapkan setelah diadakan kegiatan ini Prodi D3 Keperawatan Fakultas Keperawatan Universitas Jember mampu melakukan asuhan keperawatan secara berkesinambungan di desa binaan dan selalu melakukan perbaikan dalam melakukan kegiatan desa binaan kaitannya dengan proses pembelajaran. Kegiatan ini dapat menunjang pencapaian visi Prodi yaitu Agronursing. Kegiatan ini akan selalu dilakukan monitoring dan evaluasi bersama, dan dirumuskan Konsep Paper untuk diajukan ke pemegang kebijaan (Dinas Kesehatan), DPRD, serta Bupati sehingga terbentuk komitmen bersama dan adanya dukungan perundangan/kebijakan, pendanaan dan sebagainya. 
Maksud dan tujuan Desa Binaan ini adalah sebagai salah satu bentuk hilirisasi Tridarma Perguruan Tinggi dan sebagai bentuk tanggung jawab Prodi D3 Keperawatan F.Kep Unej dalam pemberdayaan masyarakat menuju pembangunan dan peningkatan derajat kesehatan. Adapun tujuan kegiatan FASTER berbasis Budaya adalah sebagai berikut :

1. Menggali dan meningkatkan potensi baik fisik maupun non fisik yang ada di desa Ranu Pakis dengan pendekatan budaya

2. Memperluas wawasan dan mempermudah akses warga terhadap informasi dan keilmuan masyarakat pedesaan sebagai upaya pembentukan kualitas SDM yang hebat bermartabat

3. Mengoptimalkan peran masing-masing komponen yang terlibat dalam penanganan kesehatan khususnya imunisasi (Puskesmas, Forkopimca, kader, tokoh masyarakat)

4. Membentuk forum komunikasi lintas sektor dan jejaring yang efektif dalam rangka memahamkan pentingnya kesehatan khususnya imunisasi

5. Menyinergikan program-program yang diadakan oleh Pemerintah (daerah dan desa) dalam rangka membangun masyarakat sehat, sejahtera dan bermartabat

6. Mewujudkan branding desa wisata edukasi dalam menyokong program Kabupaten Lumajang yaitu 1 kecamatan terdapat 1 desa wisata.
HASIL DAN PEMBAHASAN

Tabel 1. Hasil

\begin{tabular}{|c|c|c|c|c|}
\hline \multirow{2}{*}{ No } & \multirow{2}{*}{ Jenis Luaran } & \multicolumn{3}{|c|}{ Indikator Capaian (tahun) } \\
\hline & & 1 & 2 & 3 \\
\hline 1 & Konsep Paper & Draft & Ada & Ada \\
\hline 2 & $\begin{array}{l}\text { Komintmen bersama } \\
\text { lintas sektor serta JPP } \\
\text { (Janji Perbaikan } \\
\text { Layanan) }\end{array}$ & Ada & Ada & Ada \\
\hline \multirow[t]{7}{*}{3} & $\begin{array}{l}\text { Media Publikasi } \\
\text { berbasis budaya }\end{array}$ & Ada & Ada & Ada \\
\hline & a. Video & & & \\
\hline & b. Leflet & Ada & Ada & Ada \\
\hline & $\begin{array}{l}\text { c. Dinding pendidikan } \\
\text { (Mural) }\end{array}$ & $\begin{array}{l}\text { Draft } \\
\text { design }\end{array}$ & Ada & Ada \\
\hline & d. Perpusdes & Ada & Ada & Ada \\
\hline & e. Modul berISBN & Ada & Ada & Ada \\
\hline & f. HAKI & - & - & terdaftar \\
\hline 4 & $\begin{array}{l}\text { Publikasi pada media } \\
\text { massa baik cetak dan } \\
\text { online (Radar Semeru, } \\
\text { Unej news) }\end{array}$ & Ada & Ada & Ada \\
\hline 5 & $\begin{array}{l}\text { Jurnal Nasional } \\
\text { terakdresitasi }\end{array}$ & draft & Accepted & publishec \\
\hline 6 & Branding desa Impian & $\begin{array}{l}\text { Grand } \\
\text { design }\end{array}$ & terbentuk & replikasi \\
\hline
\end{tabular}

Tabel 2. FGD tahap pertama dilakukan dengan petugas kesehatan dengan hasil

\begin{tabular}{|c|c|c|c|}
\hline \multirow{2}{*}{ No. } & \multirow{2}{*}{ Identifikasi Masalah } & \multicolumn{2}{|c|}{ Solusi } \\
\hline & & Internal & Eksternal \\
\hline 1. & $\begin{array}{l}\text { Pola pikir orang tua bahwa setelah di imunisasi balita akan } \\
\text { sakit (rewel, panas) serta imunisasi haram }\end{array}$ & $\begin{array}{l}\text { Memberi pemahaman yang lebih } \\
\text { pada msyarakat dengan SD rendah }\end{array}$ & $\begin{array}{l}\text { Kerjasama dengan sekolahan } \\
\text { memberi penyuluhan tentang } \\
\text { imniasi ke siswanya (SD, SMP, } \\
\text { MI, MA, Mts) di Ranupakis }\end{array}$ \\
\hline 2. & Rendahnya kesadaran & $\begin{array}{l}\text { Sosialisasi ke sekolah-sekolah } \\
\text { agar anak melanjutkan ke jenjang } \\
\text { pendidikan yang lebih tinggi }\end{array}$ & $\begin{array}{l}\text { Kerjasama dengan Dinas untuk } \\
\text { membuat aturan memperpanjang } \\
\text { tingkat pendidikan (Minimal } \\
\text { SMA/ Sederajat) }\end{array}$ \\
\hline 3. & Kurangnya dukungan keluarga (Bapak) & $\begin{array}{l}\text { Masuk ke forum masyarakat } \\
\text { misalnya : pengajian untuk } \\
\text { memberi penyuluhan untuk } \\
\text { imunisasi (TOGA dan TOMA) }\end{array}$ & $\begin{array}{l}\text { Bekerjasama dengan UPT } \\
\text { Pendidikan terkait melaksanakan } \\
\text { program kejar paket }\end{array}$ \\
\hline 4. & SDM rendah (Pekerjaan) & $\begin{array}{l}\text { Memberi pemahaman } \\
\text { keluarga oleh tim terpada } \\
\text { (Puskesmas dan Lintas } \\
\text { terkait) }\end{array}$ & Mengadakan kelas imunisasi \\
\hline 5. & & $\begin{array}{l}\text { Jemput bola "PELUMAS" } \\
\text { (Pelayanan Imunisasi Rumah } \\
\text { Masyarakat) }\end{array}$ & $\begin{array}{l}\text { Dukungan Lintas sektor } \\
\text { (Ketua RT/RW s.d Kades) dan } \\
\text { bekerjasama dengan MUI }\end{array}$ \\
\hline 6. & & & $\begin{array}{l}\text { Penerbitan Perda dan himbaun } \\
\text { dari Pemda dan MUI tentang } \\
\text { anjuran imunisasi }\end{array}$ \\
\hline 7. & & & $\begin{array}{l}\text { Honorer atau operasional } \\
\text { petugas di posyandu tingkat KI }\end{array}$ \\
\hline
\end{tabular}


Tabel 3. FGD tahap kedua dilakukan dengan masyarakat dengan hasil

\begin{tabular}{|c|c|c|c|}
\hline \multirow{2}{*}{ No. } & \multirow{2}{*}{ Identifikasi Masalah } & \multicolumn{2}{|c|}{ Solusi } \\
\hline & & Internal & Eksternal \\
\hline 1. & $\begin{array}{l}\text { Kurangnya sosialisa tentang : jenis imu- } \\
\text { nisasi dan manfaat imunisasi }\end{array}$ & Silaturrahmi & $\begin{array}{l}\text { Mendatangkan oetugas } \\
\text { penyuluhan daru Pusk- } \\
\text { esms ata Dinkes yang } \\
\text { membidangi imunisasi } \\
\text { melalui kegiatan Po- } \\
\text { syandu }\end{array}$ \\
\hline
\end{tabular}

2. Di posyandu Nangkaan masih ada yang Mengadakan sosialisasi menolak imunisasi dikarenakan dapat mengakibatkan anaknya panas

3. Masih sering lupa terhadap jadwal imu- kompres nisasi

4. Tidak maunya hadir karena telah Mengumumkan kembali mendapatkan imuniasi lengkap jadwal imunisasi

5. Masyarakat mengelh mengenai cara Diadakan pendekatan menangani balita yang panas setelah imu- bersama KAKU, TOMA nisasi dan meminta sosialisasinya dan TOGA

6. Terlalu mengikuti kebiasaan dulu sehing- Mengadakan penyulhan ga tidak percaya pada imunisasi kepada masyarakat jika bayi tida imunisasi

7. Sulitnya menyakinkan orang tua untuk membawa anaknya untuk melakukan imunisasi (ada orang tua yang menolak imunisasi)

8. Masih ada masyarakat yang tidak mau di imunisasi

\section{KESIMPULAN}

Terdapat perbedaan tingkat pengetahuan sebelum dan setelah kegiatan pemberdayaan; Terdapat perbedaan sikap responden sebelum dan setelah kegiatan pemberdayaan; Terdapat perbedaan motivasi responden sebelum dan setelah kegiatan pemberdayaan; Kegiatan pemberdayaan kader efektif dalam peningkatan pengetahuan, sikap dan motivasi responden; Meningkatnya jumlah kader posyandu yang aktif; Peningkatan pengetahuan kader posyandu tentang pelaksanaan imunisasi; Meningkatnya ketrampilan kader posyandu dalam pelaksanaan imunisasi.

\section{DAFTAR PUSTAKA}

IDAI. Pedoman Imunisasi IDAI 2017. Jakarta : IDAI

Noerjoedianto, D. \& Andy, A. (2014). Penguatan Kader Posyandu dalam Upaya Deteksi Dini Kesehatan Ibu, Bayi, dan Balita di Wilayah Kecamatan Telanaipura Kota Jambi Tahun 2013. Jurnal Pengabdian Masyarakat . 29, (4)

Kemenkes RI. 2014. Buku Ajar Imuniasai. Jakarta: Kementrian Kesehatan RI
Kemenkes RI. 2016. Pedoman Umum Program Indonesia Sehat dengan Pendekatan Keluarga.

Jakarta: Kementerian Kesehatan RI

Riasmini, N.M. (2017). Panduan Asuhan Keperawatan individu, Keluarga, Kelompok. Jakarta : UI Press

Stanhope (2016). Public Health Nursing : Population Centered Health Care in the Community. USA : Mosby

Tisnawati, D. (2018). Penerapan Model Edukasi Pada Kader Kesehatan Dalam Peningkatan Cakupan Imunisasi Dasar di Wilayah Kerja Puskesmas Nanggalo Kota Padang Tahun 2017. Jurnal Pengabdian Masyarakat. Vol XII

Triana, V. 2016. Faktor yang berhubungan dalam pemberian Imunisasi. Jurnal Kesehatan Masyarakat Andalas.

Widagdo, W. \& Kholifah, S.N (2016). Keperawatan Keluarga dan Komunitas. Jakarta : Pusdik SDM Kesehatan 